\title{
Origins of Fermentation Products Formed during Growth of Bacteroides ruminicola on Glucose
}

\author{
By D. O. MOUNTFORT* AND A. M. ROBERTON \\ Department of Biochemistry, University of Auckland, Private Bag, \\ Auckland, New Zealand
}

(Received 15 December 1977)

\begin{abstract}
Bacteroides ruminicola grown on complex medium with glucose as carbon source gave acetate, $\mathrm{CO}_{2}$, formate and succinate as main fermentation products. No evidence was found for significant glucose catabolism by pathways other than the Embden-Meyerhof sequence. However, [U- $\left.{ }^{14} \mathrm{C}\right]$ glucose fermentation gave products whose specific radioactivities were much lower than expected. There appear to be two main causes. Firstly, a rapid exchange occurred between metabolic intermediates and $\mathrm{CO}_{2}$, probably due to reversibility of the pathway between phosphoenolpyruvate and fumarate. Secondly, non-glucose precursors, mainly peptides and acetate, added to the medium as growth factors, also gave rise to the above end-products. The distortions that such reactions introduce into measurements of ATP molar growth yields based on product analyses and measurements of carbon flux based on radioactivity recovered in products are discussed.
\end{abstract}

\section{INTRODUCTION}

Bacteroides ruminicola grown on glucose gives very high molar growth yields (Howlett et al., 1976) as does Bacteroides fragilis grown on glucose (Macy, Probst \& Gottschalk, 1975) and Bacteroides amylophilus grown on maltose (Hobson \& Summers, 1967). Calculations of ATP molar growth yields from such data depend on a knowledge of the pathway(s) of substrate catabolism, accurate estimates of ATP yields from substrate level phosphorylation, and unmeasured (and thus uncertain) ATP yields from electron transport-linked phosphorylation (Mountfort \& Roberton, 1977). The first two factors are usually ascertained from measurements of fermentation products and, where possible, from studies on enzymes and radioactive substrates. Where bacteria are grown in complex medium, difficulties in interpretation arise when a portion of the 'products' is made from compounds other than the major supplied energy source, even when growth is proportional to the quantity of energysubstrate added. In addition, the transfer of radioactive material from substrate into products can be complicated by unexpected exchange reactions.

In Bacteroides, hexoses and disaccharides are assumed to be fermented by the EmbdenMeyerhof pathway as far as phosphoenolpyruvate (PEP). However, Caldwell, Keeney \& van Soest (1969) have shown that the radioactivity incorporated into succinate, the main product from [U-14 C]maltose fermentation by $B$. amylophilus growing in a defined medium, was less than expected. They concluded that a pathway involving $\mathrm{CO}_{2}$ fixation could account for $60 \%$ of the succinate formed, but further study was required to decide whether this or another pathway accounted for the remaining $40 \%$. In this paper we have studied glucose fermentation by $B$. ruminicola in complex medium to see how much of the fermentation products arises from glucose carbon, and whether all glucose fermented can be accounted for by the Embden-Meyerhof pathway.

\footnotetext{
* Present address: Cawthron Institute, P.O. Box 175, Nelson, New Zealand.
} 


\section{METHODS}

Bacterium. Bacteroides ruminicola, strain $\mathrm{B}_{1} 4$, was maintained as previously described (Howlett et al., 1976). The strain was kindly supplied by Professor M. P. Bryant of the University of Illinois. Its growth and nutrition were reported by Bryant et al. (1958) and Bryant \& Robinson (1962).

Medium for growth of liquid cultures. In experiments using radioactive materials, the medium contained (per litre): $75 \mathrm{ml}$ mineral one $\left[0.6 \%(\mathrm{w} / \mathrm{v}) \mathrm{K}_{2} \mathrm{HPO}_{4}\right], 75 \mathrm{ml}$ mineral two $\left[0.6 \%(\mathrm{w} / \mathrm{v}) \mathrm{KH}_{2} \mathrm{PO}_{4}, 0.6 \%(\mathrm{w} / \mathrm{v})\right.$ $\left(\mathrm{NH}_{4}\right)_{2} \mathrm{SO}_{4}, 1 \cdot 2 \%(\mathrm{w} / \mathrm{v}) \mathrm{NaCl}, 0.245 \%$ (w/v) $\mathrm{MgSO}_{4} .7 \mathrm{H}_{2} \mathrm{O}$ and $0.159 \%(\mathrm{w} / \mathrm{v}) \mathrm{CaCl}_{2} .2 \mathrm{H}_{2} \mathrm{O}$ ] (Latham \& Sharpe, 1971), $10 \mathrm{~g}$ Trypticase (Baltimore Biological Laboratories), $2 \mathrm{~g}$ yeast extract, $2.5 \mathrm{mg}$ haemin, $1.0 \mathrm{mg}$ resazurin, $4 \mathrm{~g} \mathrm{CO}_{2}$-equilibrated sodium carbonate, $5 \mathrm{~g}$ cysteine hydrochloride, $1 \mathrm{~g}$ glucose, and $100 \% \mathrm{CO}_{2}$ gas phase, prepared and made anaerobic as previously described (Howlett et al., 1976), unless otherwise indicated. The inoculum was grown to two-thirds of full growth in $5 \mathrm{ml}$ of non-radioactive medium; it was then centrifuged anaerobically $(1700 \mathrm{~g}, 10 \mathrm{~min})$ and resuspended in $2 \mathrm{ml}$ of radioactive medium, and $0.1 \mathrm{ml}$ portions were inoculated into $10 \mathrm{ml}$ of radioactive medium in $16 \times 150 \mathrm{~mm}$ tubes stoppered with butyl rubber bungs. Growth at $37^{\circ} \mathrm{C}$ was followed spectrophotometrically at $600 \mathrm{~nm}$.

Chemical analyses. Determinations were carried out on medium after bacteria had reached full growth and on uninoculated medium, where appropriate. Except for $\mathrm{CO}_{2}$ estimations, bacteria were removed by centrifugation $(5000 \mathrm{~g}, 10 \mathrm{~min}$ ) before analysis. Glucose was determined using the toluidine reagent as previously described (Howlett et al., 1976). Substances in uninoculated medium reacting with toluidine gave less than $1 \%$ of the colour given by added glucose. Organic acid fermentation products were separated by celite column chromatography (Swim \& Utter, 1957), and the acidity of fractions was measured by titration against $0.01 \mathrm{M}-\mathrm{NaOH}$. Recoveries of standard acids added to uninoculated medium were, acetic $94.5 \%$, formic $93 \%$, and succinic $96 \%$, and experimental values were corrected accordingly where indicated. Succinic acid isolated by this method was shown to be pure by gas-liquid chromatography of the methylated derivative as previously described (Howlett et al., 1976), and by thin-layer chromatography on cellulose plates using 1-butanol/acetic acid/water $(50: 25: 25$, by vol.) and amyl alcohol/formic acid/water $\left(40: 40: 2\right.$, by vol.) as solvents, and on silica-gel plates using ethanol/ $\mathrm{NH}_{3} /$ water $(80: 20: 10$, by vol.) as solvent.

Radiochemicals. ${ }^{14} \mathrm{C}$-Labelled compounds were obtained from The Radiochemical Centre, Amersham. [U-14 $\mathrm{C}$ ]Peptides were prepared either from a mixture of casein and commercial algal $\left[\mathrm{U}-{ }^{14} \mathrm{C}\right]$ protein $(99: 1, w / w)$ or from [U-14 C]protein extracted by the method of Roberts et al. (1957) from Chlorella cells grown in the presence of ${ }^{14} \mathrm{CO}_{2}$. The protein was digested with pancreatin in $2 \mathrm{M}$-urea $(\mathrm{pH} \mathrm{7.5)}$ for $3 \mathrm{~h}$ at $25^{\circ} \mathrm{C}$, and then urea was removed by absorption of the peptides on a Dowex $50\left(\mathrm{H}^{+}\right)$column and elution with $4 \mathrm{M}-\mathrm{NH}_{3}$ (Bennett, 1967). The carbon content of tryptone and algal peptides was kindly determined by Professor A. D. Campbell and associates, University of Otago, New Zealand.

Radiochemical measurements. A Packard Tricarb scintillation spectrometer (model 3320) was used for liquid scintillation counting, and counts were corrected for quenching by the channels ratio method. To estimate the specific radioactivity of ${ }^{14} \mathrm{CO}_{2}$, the $\mathrm{CO}_{2}$ was trapped in $3 \mathrm{M}-\mathrm{NaOH}$, as previously described (Howlett et al., 1976), and precipitated by adding $12 \%$ (w/v) $\mathrm{BaCl}_{2}$. The $\mathrm{Ba}^{14} \mathrm{CO}_{3}$ was separated by centrifuging, then washed, collected on tared filter discs, dried and weighed. Samples were scraped from filter discs, weighed, and counted in $10 \mathrm{ml}$ scintillant [ 1 vol. ethanol $/ 1$ vol. toluene containing $0.4 \%(\mathrm{w} / \mathrm{v}) 2,5$-diphenyloxazole (PPO) and $0.01 \%$ (w/v) 1,4-di-2-(5-phenyloxazolyl)benzene (POPOP)]. Loss of counting efficiency due to self-absorption of $\mathrm{BaCO}_{3}$ was estimated using $\mathrm{Na}_{2}{ }^{14} \mathrm{CO}_{3}$ standards, and was less than $5 \%$; samples were corrected accordingly. When the radioactivity, but not the mass, of $\mathrm{CO}_{2}$ was required, the gas was trapped in $10 \mathrm{ml}$ ethanolamine/methoxyethanol $(2: 1, \mathrm{v} / \mathrm{v})$ and portions were counted by the method of Jeffay \& Alvarez (1961). Radioactivity in uninoculated medium (except medium containing ${ }^{14} \mathrm{CO}_{2}$ ) was determined using duplicate samples $(0.2 \mathrm{ml})$ to which $0.8 \mathrm{ml}$ water and $10 \mathrm{ml}$ scintillant [1 vol. Triton X-100/2 vol. toluene containing $0.4 \%$ (w/v) PPO and $0.01 \%$ (w/v) POPOP] were added. Radioactivities of organic acids fractionated by chromatography on celite were also determined in this scintillant. Incorporation of radioactivity into bacteria was measured after centrifugation, a single wash with distilled water, collection on a Millipore filter $(0.8 \mu \mathrm{m}$ pore diameter), drying, and counting in the Triton X-100/toluene scintillant described above.

Degradation of $\left[{ }^{14} \mathrm{C}\right]$ succinate. Succinate, separated by celite column chromatography, was dried under reduced pressure and mixed with $0.5 \mathrm{mmol}$ of unlabelled sodium succinate. A portion $(0.2 \mathrm{mmol})$ was degraded to propionate and $\mathrm{CO}_{2}$ by the method of Swim (Swim \& Utter, 1957) using Veillonella alcalescens (ATCC 17745). The specific radioactivity of $\mathrm{CO}_{2}$ was determined as described above, and that of propionate was measured after celite column chromatography. 
Table 1. Distribution of radioactivity after fermentation of $\left[U-{ }^{14} C\right]$ glucose

\begin{tabular}{|c|c|c|}
\hline & \multicolumn{2}{|c|}{$\begin{array}{l}\text { Radioactivity present initially in } \\
\text { substrates (S) and in products ( } P \\
\text { after fermentation }\end{array}$} \\
\hline & $10^{-6} \times$ d.p.m.* & $\%$ of total \\
\hline Glucose (S) $\dagger$ & $11 \cdot 35$ & 100 \\
\hline $\mathrm{CO}_{2}(\mathrm{~S})$ & 0 & 0 \\
\hline Acetate $(P) \ddagger$ & $2 \cdot 75 \pm 0 \cdot 01$ & $24 \cdot 2$ \\
\hline Formate $(\mathbf{P}) \ddagger$ & $0.22 \pm 0.03$ & 1.9 \\
\hline Succinate $(P) \ddagger$ & $3.65 \pm 0.07$ & $32 \cdot 0$ \\
\hline $\mathrm{CO}_{2}(\mathrm{P}) \ddagger$ & $1.88 \pm 0.09$ & $16 \cdot 5$ \\
\hline Glucose not utilized $\S$ & $0.42 \pm 0.06$ & $3 \cdot 7$ \\
\hline Non-volatile unknown\| & $0.70 \pm 0.06$ & $6 \cdot 2$ \\
\hline Bacteria & $1.47 \pm 0.07$ & $13 \cdot 0$ \\
\hline Total recovery & $11.09 \pm 0.28$ & $97 \cdot 5$ \\
\hline
\end{tabular}

Table 2. Specific radioactivities of products* formed during fermentation of $\left[U-{ }^{14} C\right]$ glucose

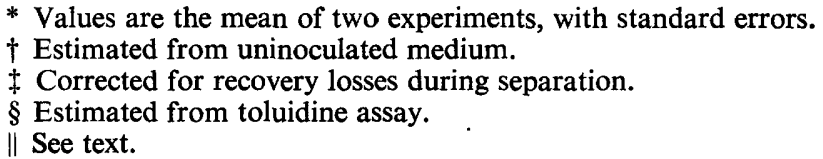

$$
10^{-4} \times
$$

Amount $\dagger$

$(\mu \mathrm{mol})$

Sp. radioactivity $\dagger$

[d.p.m. $\left(\mu\right.$ g-atom C) ${ }^{-1}$ ]

Initial glucose

Acetate

Formate

Succinate

$55 \cdot 67$
$40 \cdot 54 \pm 0 \cdot 88$
$21 \cdot 46 \pm 2 \cdot 49$
$51 \cdot 54 \pm 3 \cdot 40$

Ratio of sp.

radioactivity of product to glucose $\ddagger$

$3 \cdot 35$
$3 \cdot 15 \pm 0.06$
$0.99 \pm 0.03$
$1 \cdot 61 \pm 0.06$
$1 \cdot 00$
0.94
$0 \cdot 30$
$0 \cdot 48$

* Quantities of fermentation products and radioactivity recovered from chromatography columns were not corrected for losses during separation.

$\dagger$ Values are the mean of three experiments, with standard errors.

† Specific radioactivities expressed as d.p.m. $(\mu \mathrm{g} \text {-atom } \mathrm{C})^{-1}$.

\section{RESULTS}

\section{Fermentation of $\left[U_{-14}{ }^{14}\right]$ glucose}

At full growth, the distribution of radioactivity in products of [U- $\left.{ }^{14} \mathrm{C}\right]$ glucose fermentation was $16.5 \%$ in $\mathrm{CO}_{2}, 32 \%$ in succinate, $24 \%$ in acetate, and $2 \%$ in formate (Table 1 ). The bacteria contained $13 \%$ of the added radioactivity, most of which was probably located in internal polysaccharide (Howlett et al., 1976). Uncharacterized material was present in the supernatant, accounting for $6.2 \%$ of the original radioactivity. This material was not glucose, but was anthrone-positive ( $5 \%$ of the original glucose when assayed chemically), toluidine-negative, insoluble in ether in acidic conditions and non-volatile, suggesting that at least part of it was polysaccharide. The overall recovery of radioactivity was $97.5 \%$. The specific radioactivities of the products [expressed as d.p.m. ( $\mu$ g-atom $\mathrm{C}^{-1}{ }^{-1}$ are presented in Table 2. The ratios of the specific radioactivities of products to glucose were: succinate $0 \cdot 48$, acetate 0.94 and formate 0.30 . Theoretical ratios, assuming that (i) succinate is made by $\mathrm{CO}_{2}$ fixation into PEP, (ii) the Embden-Meyerhof pathway operates, and (iii) no exchange reactions occur,"are $0.75,1.00$ and 1.00 .

\section{Metabolism of ${ }^{14} \mathrm{CO}_{2}$ during growth on unlabelled glucose}

Although over $90 \%$ of the initial radioactivity remained in the $\mathrm{CO}_{2}$, there was significant incorporation into succinate $(6 \cdot 1 \%)$, formate $(0.75 \%)$ and bacteria $(0.5 \%)$. The specific 
Table 3. Specific radioactivities of products* formed during fermentation of unlabelled glucose in the presence of ${ }^{14} \mathrm{CO}_{2}$

$\begin{array}{lccc}\text { Amount } & \begin{array}{c}10^{-4} \times \\ (\mu \mathrm{mol})\end{array} & \begin{array}{c}\text { Sp. radioactivity } \\ \left(\text { d.p.m. } \mu \mathrm{mol}^{-1}\right)\end{array} & \begin{array}{c}\text { Ratio of sp. } \\ \text { radioactivity of } \\ \text { product to } \mathrm{CO}_{2} \dagger\end{array} \\ \text { Initial glucose } & 58.5 & - & - \\ \text { Initial 14 }{ }^{14} \mathrm{CO}_{2} \ddagger & 1200 & 1.65 & 1.00 \\ \text { Acetate } & 42.0 & 0.03 & 0.02 \\ \text { Formate } & 18.0 & 0.70 & 0.42 \\ \text { Succinate } & 56.0 & 2.25 & 1.36\end{array}$

\footnotetext{
* Quantities of fermentation products and radioactivity recovered from chromatography columns were not corrected for losses during separation.

$\dagger$ Specific radioactivities expressed as d.p.m. $\mu \mathrm{mol}^{-1}$.

$\ddagger$ Estimated from uninoculated duplicate tube: ${ }^{14} \mathrm{CO}_{2}$ was added as sterile $\mathrm{Na}_{2} \mathrm{CO}_{3}$ solution.
}

Table 4. Distribution of radioactivity after fermentation of $\left[1-{ }^{14} \mathrm{C}\right]$ glucose

\begin{tabular}{|c|c|c|}
\hline & $\begin{array}{r}\text { Radioactivity } \\
\text { substrates (S) } \\
\text { after f }\end{array}$ & $\begin{array}{l}\text { nitially in } \\
\text { oducts (P) } \\
\text { on }\end{array}$ \\
\hline & $10^{-6} \times$ d.p.m. ${ }^{*}$ & $\%$ of total \\
\hline Glucose (S) $\dagger$ & $4 \cdot 5$ & 100 \\
\hline $\mathrm{CO}_{2}(\mathrm{~S})$ & 0 & 0 \\
\hline Acetate $(\mathrm{P}) \ddagger$ & $1.49 \pm 0.004$ & 33 \\
\hline Formate (P) $\ddagger$ & $0.06 \pm 0.01$ & $1 \cdot 2$ \\
\hline Succinate $(\mathbf{P}) \ddagger$ & $1.53 \pm 0.004$ & 34 \\
\hline $\mathrm{CO}_{2}(\mathrm{P}) \ddagger$ & $0.09 \pm 0.02$ & $2 \cdot 0$ \\
\hline Glucose not utilized§ & $0.12 \pm 0.005$ & $2 \cdot 8$ \\
\hline Non-volatile unknown $\|$ & $0.12 \pm 0.007$ & $2 \cdot 7$ \\
\hline Bacteria & $0.69 \pm 0$ & $15 \cdot 4$ \\
\hline Total recovery & $4.09 \pm 0.025$ & $91 \cdot 2$ \\
\hline
\end{tabular}

Footnotes as in Table 1.

radioactivities (d.p.m. $\mu \mathrm{mol}^{-1}$ ) of $\mathrm{CO}_{2}$ added initially and end-products were: $\mathrm{CO}_{2}$ $1.65 \times 10^{4}$, succinate $2.25 \times 10^{4}$, acetate $0.03 \times 10^{4}$, formate $0.7 \times 10^{4}$ (Table 3 ). The ratio of the specific radioactivities of succinate to $\mathrm{CO}_{2}$ was $1 \cdot 36$, i.e. 0.36 greater than expected if $1 \mathrm{~mol}$ $\mathrm{CO}_{2}$ were fixed per mol succinate formed in the absence of $\mathrm{CO}_{2}$ exchange. When the succinate was degraded, using $V$. alcalescens cells, to propionate and $\mathrm{CO}_{2}$, these compounds showed 48.7 and $48 \%$, respectively, of the specific radioactivity (expressed as d.p.m. $\mu \mathrm{mol}^{-1}$ ) of the succinate (results not shown). These results indicated that the extra ${ }^{14} \mathrm{C}$ in succinate resulted from ${ }^{14} \mathrm{CO}_{2}$ incorporation exclusively into the carboxyl carbon atoms of succinate as the specific radioactivities of the degradation products, propionate and $\mathrm{CO}_{2}$, were equal. Formate had a specific radioactivity 0.4 times that of $\mathrm{CO}_{2}$, i.e. $0.4 \mu \mathrm{g}$-atom more radioactivity per mol formate than expected, indicating that a $\mathrm{CO}_{2}$-exchange reaction was indeed operating. The acetate formed during ${ }^{14} \mathrm{CO}_{2}$ metabolism had a negligible specific radioactivity.

A possible explanation for the higher than expected specific radioactivities of succinate and formate is that the pathway between fumarate and PEP (or pyruvate) is reversible. When fumarate is formed from PEP, the first carboxyl group will become labelled, and when fumarate is metabolized back to the $\mathrm{C}_{3}$ compound, theoretically only $50 \%$ of the label will be lost. Further metabolism to formate or back to succinate will then give higher than expected counts in these products. This hypothesis of fumarate exchange with $\mathrm{C}_{3}$ intermediates was tested in the following experiment. 
Table 5. Specific radioactivities of products* formed during fermentation of $\left[1-{ }^{14} \mathrm{C}\right]$ glucose

\begin{tabular}{|c|c|c|c|}
\hline & $\underset{(\mu \mathrm{mol})}{\text { Amount }} \uparrow$ & $\begin{array}{c}10^{-4} \times \\
\text { Sp. radioactivity } \dagger \\
\text { (d.p.m. } \mu \mathrm{mol}^{-1} \text { ) }\end{array}$ & $\begin{array}{l}\text { Ratio of sp. } \\
\text { radioactivity of } \\
\text { product to glucose }\end{array}$ \\
\hline Initial glucose & $49 \cdot 5$ & $9 \cdot 28$ & 1.00 \\
\hline Acetate & $37 \cdot 7 \pm 1.99$ & $4 \cdot 10 \pm 0 \cdot 15$ & 0.44 \\
\hline Formate & $19.9 \pm 0.08$ & $0.28 \pm 0.05$ & 0.03 \\
\hline Succinate & $49 \cdot 2 \pm 0 \cdot 40$ & $3.13 \pm 0.04$ & $0 \cdot 34$ \\
\hline
\end{tabular}

* Quantities of fermentation products and radioactivity recovered from chromatography columns were both corrected for losses during separation.

$\dagger$ Values are the mean of two experiments, with standard errors.

$\ddagger$ Specific radioactivities expressed as d.p.m. $\mu \mathrm{mol}^{-1}$.

\section{Metabolism of $\left[2,3-{ }^{14} \mathrm{C}\right]$ fumarate during growth on unlabelled glucose}

When $19 \mu \mathrm{mol}\left[2,3-{ }^{14} \mathrm{C}\right]$ fumarate was added to bacteria fermenting $53 \mu \mathrm{mol}$ unlabelled glucose, some ${ }^{14} \mathrm{C}$ from fumarate was incorporated into both acetate and succinate (results not shown). The ratios of the specific radioactivities (expressed as d.p.m. $\mu \mathrm{mol}^{-1}$ ) of products to added fumarate were: acetate 0.013, succinate 0.070. During separation on the celite column, the formate and fumarate peaks overlapped, and though the formate appeared to be unlabelled no definitive results were obtained. The specific radioactivities of acetate and succinate were lower than that of added fumarate when expressed as d.p.m. ( $\mu$ g-atom $C)^{-1}$. This would be expected due to incomplete utilization of labelled fumarate and dilution of radioactive products by glucose-derived products. The specific radioactivity of succinate was higher than that of acetate, probably because carbon flux would be towards succinate. The results show that an exchange occurred between fumarate and a $C_{3}$ intermediate, despite the permeability barrier slowing transport into the cell.

\section{Fermentation of $\left[1-1^{14} \mathrm{C}\right]$ glucose}

If $\mathrm{CO}_{2}$-exchange, caused by PEP and fumarate interconversion, is solely responsible for the low specific radioactivities of succinate and formate formed during [U-14 C]glucose fermentation, then no dilution of label should occur when $\left[1-{ }^{14} \mathrm{C}\right]$ glucose is fermented. Also, with the latter substrate, extensive formation of ${ }^{14} \mathrm{CO}_{2}$ would indicate operation of the Entner-Doudoroff, hexose monophosphate and/or phosphoketolase pathways rather than the Embden-Meyerhof pathway.

The results (Table 4 ) show that only $2 \%$ of the radioactivity from $\left[1-{ }^{14} \mathrm{C}\right]$ glucose was metabolized to $\mathrm{CO}_{2}$ and the carbon recovery was $91 \%$. Recoveries of the total added radioactivity in acetate and succinate were nearly equal, suggesting that nearly equimolar concentrations of these acids were derived from $\left[1-{ }^{14} \mathrm{C}\right]$ glucose. In contrast, equal amounts were not found by titration of the supernatant (see Tables 2 and 3, and Howlett et al., 1976). When specific radioactivities (d.p.m. $\mu \mathrm{mol}^{-1}$ ) were calculated (Table 5), acetate, formate and succinate had values $0.44,0.03$ and 0.34 times that of glucose; theoretical values are $0 \cdot 50,0$ and $0 \cdot 50$. Degradation of succinate to propionate and $\mathrm{CO}_{2}$ by $V$. alcalescens (results not shown) indicated that $96 \%$ of the label was in the methylene carbon atoms.

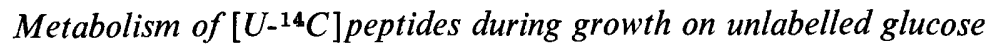

Since $\left[\mathrm{U}-{ }^{14} \mathrm{C}\right]$ Trypticase was not commercially available, $\left[\mathrm{U}-{ }^{14} \mathrm{C}\right]$ peptides were prepared from a mixture of commercial algal $\left[\mathrm{U}-{ }^{14} \mathrm{C}\right]$ protein and casein, (experiment 1 , Table 6 ) and from algal [U-14 C]protein from cells grown in this laboratory (experiment 2, Table 6). These peptides were used in growth studies. The bacteria reached full growth after $7.5 \mathrm{~h}$ and $12 \mathrm{~h}$, respectively. The slower growth in experiment 2 compared with experiment 1 could have been due to the lower peptide concentration $(35 \mathrm{mg}$ and $50 \mathrm{mg}$ peptide, respectively, per $5 \mathrm{ml}$ ) and/or to a lower acetate concentration in experiment 2 (Trypticase contains acetate). 
Table 6. Specific radioactivities of products* formed during fermentation of unlabelled glucose in the presence of $\left[U_{-11} C\right]$ peptides

\begin{tabular}{|c|c|c|c|c|c|c|}
\hline & \multicolumn{3}{|c|}{ Experiment 1} & \multicolumn{3}{|c|}{ Experiment 2} \\
\hline & $\begin{array}{c}\text { Amount } \\
(\mu \mathrm{mol})\end{array}$ & $\begin{array}{c}10^{-3} \times \\
\text { Radioactivity } \\
\text { (d.p.m.) }\end{array}$ & $\begin{array}{c}10^{-2} \times \mathrm{Sp} . \\
\text { radioactivity } \\
{[\text { d.p.m. }} \\
\left.(\mu \text { g-atom C })^{-1}\right]\end{array}$ & $\underset{(\mu \mathrm{mol})}{\text { Amount }}$ & $\begin{array}{c}10^{-5} \times \\
\text { Radioactivity } \\
\text { (d.p.m.) }\end{array}$ & $\begin{array}{c}10^{-3} \times \mathrm{Sp} \text {. } \\
\text { radioactivity } \\
\text { [d.p.m. } \\
(\mu \mathrm{g} \text {-atom C })^{-1} \text { ] }\end{array}$ \\
\hline Initial glucose & $28 \cdot 0$ & - & - & $29 \cdot 0$ & - & - \\
\hline [U-14C]Peptide & $(50 \mathrm{mg}) \dagger$ & 550 & $3 \cdot 1$ & $(35 \mathrm{mg}) \ddagger$ & 185 & $15 \cdot 1$ \\
\hline Acetate & $21 \cdot 0$ & $2 \cdot 3$ & 0.55 & $22 \cdot 0$ & $1 \cdot 13$ & $2 \cdot 5$ \\
\hline Formate & ND & ND & ND & $9 \cdot 0$ & 0.415 & $4 \cdot 5$ \\
\hline Succinate & $26 \cdot 0$ & $3 \cdot 56$ & 0.34 & $26 \cdot 0$ & 1.44 & $1 \cdot 39$ \\
\hline
\end{tabular}

* Quantities of fermentation products and radioactivity recovered from chromatography columns were not corrected for losses during separation.

$\dagger$ Peptide made by digestion of mixture of casein and commercial algal [U-14 C]protein; measured $\mathrm{C}$ content $41.9 \%$.

$\ddagger$ Peptide made by digestion of $\left[\mathrm{U}-{ }^{14} \mathrm{C}\right]$ protein extracted from Chlorella; measured $\mathrm{C}$ content $42 \cdot 5 \%$.

The ratio of the specific radioactivities [expressed as d.p.m. ( $\mu \mathrm{g}$-atom C) ${ }^{-1}$ ] of succinate to peptides was 0.11 in experiment 1 , and 0.093 in experiment 2 . These are minimum values. A correction of unknown magnitude needs to be made for label dilution due to possible $\mathrm{CO}_{2}$ fixation into $\mathrm{C}_{3}$ precursors and carboxyl group exchange with $\mathrm{CO}_{2}$. The position of the label in the succinate was not determined. The ratio of specific radioactivities of acetate formed to peptides was 0.177 in experiment 1 and $0 \cdot 165$ in experiment 2 . These values were higher than predicted from the studies with $\left[\mathrm{U}-{ }^{14} \mathrm{C}\right]$ - and $\left[1-{ }^{14} \mathrm{C}\right] \mathrm{glucose}$ but could have been due to the difference in amino acid constituents of Trypticase and algal peptides. The ratio of the specific radioactivities of formate to peptides was $0 \cdot 3$.

\section{Metabolism of $\left[2-{ }^{14} \mathrm{C}\right]$ acetate during growth on unlabelled glucose}

Since acetate was the major volatile fatty acid present in uninoculated medium and was required for optimal growth, the incorporation of radioactive acetate into other products was studied. Unlabelled glucose $(53 \mu \mathrm{mol})$ was fermented in the presence of $119 \mu \mathrm{mol}$ $\left[2-{ }^{14} \mathrm{C}\right]$ acetate (results not shown). About $95 \%$ of the added acetate was not metabolized. However, $4.5 \%$ was transformed into succinate, and the specific radioactiv ${ }^{\text {i. }}{ }^{\prime}$ of succinate (expressed as d.p.m. $\mu \mathrm{mol}^{-1}$ ) was $0 \cdot 11$ times that of the initial acetate. This $s$ a minimum value since acetate radioactivity would have been diluted by acetate production during growth. Little significant incorporation of acetate into formate occurred, this product having 0.01 times the specific radioactivity of added ace .

\section{Metabolism of other ${ }^{14} \mathrm{C}$-labelled compounds during growth on unlabelled glucose}

$\mathrm{L}-\left[\mathrm{U}-{ }^{14} \mathrm{C}\right] \mathrm{Cysteine}$ and $\left[2-{ }^{14} \mathrm{C}\right]$ propionate were tested for incorporation into products (data not shown). In the presence of $\left[\mathrm{U}-{ }^{14} \mathrm{C}\right]$ cysteine, the ratios of the specific radioactivities [expressed as d.p.m. ( $\mu$ g-atom $C)^{-1}$ ] of products to cysteine were: formate 0.03 , acetate 0.03 , succinate 0.005 . The corresponding values in the presence of $\left[2-{ }^{14} \mathrm{C}\right]$ propionate (with specific radioactivities expressed as d.p.m. $\mu \mathrm{mol}^{-1}$ ) were: acetate 0.005 , succinate 0.008 . Thus, incorporation from these compounds was small.

\section{DISCUSSION}

Pathways of glucose catabolism. Studies on $\left[1^{-14} \mathrm{C}\right]$ glucose catabolism indicate that the Entner-Doudoroff, phosphoketolase and hexosemonophosphate shunt pathways are not major routes of glucose utilization, because radioactivity incorporated into $\mathrm{CO}_{2}$ was too 
low (Table 4). Labelling patterns of other products formed from $\left[1-{ }^{14} \mathrm{C}\right]$ glucose (Table 5 and text) were consistent with a high proportion of glucose being metabolized via the EmbdenMeyerhof pathway, the methylene carbon atoms containing $96 \%$ of the label in succinate, and $\mathrm{CO}_{2}$ and formate being virtually unlabelled. Acetate, formate and $\mathrm{CO}_{2}$ are thought to be formed in B. ruminicola from pyruvate catabolism, and succinate via PEP carboxykinasemediated $\mathrm{CO}_{2}$-fixation to oxaloacetate (Scardovi \& Chiappini, 1966). Aldolase (Joyner \& Baldwin, 1966), hexosephosphate isomerase and phosphofructokinase (P. G. Glucina \& A. M. Roberton, unpublished results) are known to be present. However, although the labelling patterns and enzyme studies are consistent with operation of the Embden-Meyerhof pathway for glucose catabolism, it is still necessary to explain the unexpectedly low specific radioactivities of some products formed during $\left[\mathrm{U}^{-14} \mathrm{C}\right] \mathrm{glucose}$ and $\left[1-{ }^{14} \mathrm{C}\right] \mathrm{glucose}$ catabolism.

Studies on [U-14 C]maltose fermentation in B. amylophilus by Caldwell et al. (1969) using a defined medium showed that the specific radioactivity of succinate, when expressed as d.p.m. $(\mu \mathrm{g} \text {-atom C) })^{-1}$, was lower than expected. They also showed that ${ }^{14} \mathrm{CO}_{2}$ was incorporated into the carboxyl groups of succinate. We find similar results with $B$. ruminicola fermenting $\left[\mathrm{U}-{ }^{14} \mathrm{C}\right] \mathrm{glucose}$, and have made further studies to be certain that such results are consistent with the Embden-Meyerhof pathway. Several factors appear to contribute to the unexpected specific radioactivities of products from labelled glucose. (i) $\mathrm{CO}_{2}$ exchange (in addition to $\mathrm{CO}_{2}$ fixation) occurred into the carboxyl groups of succinate and formate. This was catalysed by a reversible pathway between PEP and fumarate. The extent can be estimated from ${ }^{14} \mathrm{CO}_{2}$ incorporation measurements (Table 3) in which succinate and formate had, respectively, 0.36 and $0.42 \mu \mathrm{g}$-atom more ${ }^{14} \mathrm{C}$ than expected. (ii) Non-glucose precursors contributed to formation of succinate, acetate and formate. Their contribution to succinate production can be deduced from experiments using $\left[1{ }^{14} \mathrm{C}\right]$ glucose, which does not exchange label with $\mathrm{CO}_{2}$. The data in Table 5 suggest that a minimum of $68 \%$ of succinate was derived from glucose, and a maximum of $32 \%$ was derived from non-glucose precursors. A theoretical calculation of the expected specific radioactivity of succinate, produced from [U-14 $\mathrm{C}$ ]glucose in the presence of $\mathrm{CO}_{2}$ exchange and non-glucose precursors, can be made by multiplying the fraction of unlabelled carbon atoms in succinate formed in the presence of ${ }^{14} \mathrm{CO}_{2}[(4 \cdot 00-1 \cdot 36) / 4]$ by the fraction of succinate labelled from $\left[1{ }^{14} \mathrm{C}\right]$ glucose catabolism $[0 \cdot 34 / 0 \cdot 50]$. Thus a minimum of 0.45 of the carbon atoms in succinate formed during [U-14 C]glucose fermentation should be labelled. This is in good agreement with the experimentally determined value of 0.48 (Table 2).

Experiments using $\left[{ }^{14} \mathrm{C}\right]$ peptides and $\left[2{ }^{-14} \mathrm{C}\right]$ acetate suggest that these compounds are the major non-glucose precursors of fermentation products. $\left[{ }^{14} \mathrm{C}\right]$ Peptides contributed a minimum of $10 \%$ of the succinate formed during glucose catabolism (Table 6). This value may have depended on the amino acid content of the peptides used, and could have been greater if $\mathrm{CO}_{2}$ exchanges with precursor carboxyl groups. Peptides also contributed to acetate and formate formation, values of 17 and $30 \%$ being found, respectively (Table 6). The ratio of the specific radioactivities [expressed as d.p.m. $(\mu \mathrm{g} \text {-atom C })^{-1}$ ] of formate to peptides was higher than expected. Perhaps formate may have been formed directly from such peptide constituents as glycine and serine, in addition to the pathways from $\mathrm{C}_{3}$ precursors common to acetate production; more acetate than formate is formed from glucose. Finally $\left[2-{ }^{14} \mathrm{C}\right]-$ acetate gave rise to labelled succinate (a minimum of $11 \%$ ) and this could indicate either exchange and/or net incorporation.

Stoicheiometry of glucose fermented to products derived from glucose. Data in Tables 1, 2, 4 and 5 show a measured stoicheiometry of glucose disappearing from the medium to products of $1 \mathrm{~mol}$ glucose : $1.02 \mathrm{~mol}$ succinate, $0.80 \mathrm{~mol}$ acetate (and $0.41 \mathrm{~mol}$ formate). To find the portion of glucose fermented to products, one must subtract $19.2 \%$ (glucose converted to cell material and non-volatile unknown, see Table 1). To estimate the products actually formed from fermented glucose, a correction can be made on the basis of lowered 
specific radioactivity values (Table 5); i.e. $68 \%$ of 1.02 mol succinate per mol glucose and $88 \%$ of $0.80 \mathrm{~mol}$ acetate per mol glucose. Formate can be ignored in energy calculations.

In essence, for every $1 \mathrm{~mol}$ glucose disappearing from the medium, only $0.808 \mathrm{~mol}$ was fermented to give energy, and $0.695 \mathrm{~mol}$ succinate and $0.705 \mathrm{~mol}$ acetate were produced from this. From non-glucose sources, $0.32 \mathrm{~mol}$ succinate and $0.10 \mathrm{~mol}$ acetate were produced.

ATP yields. Assuming zero net ATP yield during glucose transformation to PEP, the substrate level phosphorylation reactions giving rise to ATP are PEP carboxykinase, pyruvate kinase and acetokinase. The ATP yield from $0.808 \mathrm{~mol}$ glucose will be $2 \cdot 1$ to $2 \cdot 3$ ATP by such reactions, i.e. $2 \cdot 6$ to $2 \cdot 8$ ATP per mol glucose. The reactions yielding unknown amounts of ATP are those from peptides to succinate and acetate, anaerobic electron transport-linked phosphorylation, and acetate to succinate (energy requiring). The data in this paper clearly show the difficulties inherent in estimating ATP yields from product analysis. A substantial portion of 'products' was not made from the energy source in complex medium; corrections had to be made for assimilation of substrate into cell material and extracellular products, and the use of radioactive substrates shows that exchange reactions obscured the true recovery of products. Only when such factors are assessed will growth yield experiments be meaningful. Such considerations will also be important in studies on pure or mixed cultures in which the radioactivity found in products is used as a measure of the breakdown of an added radioactive substrate.

\section{REFERENCES}

BENNETT, J. C. (1967). Denaturation of polypeptide substrates. Methods in Enzymology 11, 211-213.

Bryant, M. P. \& Robinson, I. M. (1962). Some nutritional characteristics of predominant culturable ruminal bacteria. Journal of Bacteriology 84, 605-614.

Bryant, M. P., Small, N., Bouma, C. \& Chu, H. (1958). Bacteroides ruminicola n.sp. and Succinimonas amylolytica the new genus and species. Species of succinic acid-producing anaerobic bacteria of the bovine rumen. Journal of Bacterio$\log y$ 76, 15-23.

Caldwell, D. R., Keeney, M. \& van Soest, P. J. (1969). Effects of carbon dioxide on growth and maltose fermentation by Bacteroides amylophilus. Journal of Bacteriology 98, 668-676.

Hobson, P. N. \& Summers, R. (1967). The continuous culture of anaerobic bacteria. Journal of General Microbiology 47, 53-65.

* Howlett, M. R., Mountfort, D. O., Turner, K. W. \& Roberton, A. M. (1976). Metabolism and growth yields in Bacteroides ruminicola strain $\mathbf{B}_{1} 4$. Applied and Environmental Microbiology 32, 274-283.

JefFAy, H. \& Alvarez, J. (1961). Liquid scintillation counting of carbon-14: use of ethanolamineethyleneglycol monomethylether-toluene. Analytical Chemistry 33, 612-615.

JoYNER, A. E., Jr, \& BALDWIN, R. L. (1966). Enzymatic studies of pure cultures of rumen microorganisms. Journal of Bacteriology 92, 13211330.
Latham, M. J. \& Sharpe, M. E. (1971). The isolation of anaerobic organisms from the bovine rumen. In Isolation of Anaerobes, Society for Applied Bacteriology Technical Series No. 5, pp. 133-147. Edited by D. A. Shapton and R. G. Board. London: Academic Press.

Macy, J., Probst, I. \& GotTschalk, B. (1975). Evidence for cytochrome involvement in fumarate reduction and ATP synthesis by Bacteroides fragilis grown in the presence of haem. Journal of Bacteriology 123, 436-442.

Mountfort, D. O. \& Roberton, A. M. (1977). The role of menaquinone and $b$-type cytochrome in anaerobic reduction of fumarate by NADH in membrane preparations from Bacteroides ruminicola strain $\mathrm{B}_{1} 4$. Journal of General Microbiology 100, 309-317.

Roberts, R. B., Abelson, P. H., Cowie, D. B., Bolton, E. T. \& BRITTEN, R. J. (1957). Studies of biosynthesis in Escherichia coli. Carnegie Institution of Washington Publication 607. Washington: Carnegie Institution of Washington.

Scardovi, V. \& ChIAPPINI, M. G. (1966). Studies in rumen bacteriology. V. Carboxylation of phosphoenolpyruvate in some rumen bacterial strains and in the cell-free extract of the total rumen flora. Annali di microbiologia ed enzimologia 16, 119-127.

SwIM, H. E. \& UTTER, M. F. (1957). Isotopic experimentation with intermediates of the tricarboxylic acid cycle. Methods in Enzymology 4, 584-609. 